\title{
THE ROLE OF INTEGRATED ISLAMIC COMMERCIAL AND SOCIAL FINANCE FOR CURBING CREDIT CYCLES AND ACHIEVING MACROPRUDENTIAL OBJECTIVE
}

\author{
Arif Widodo ${ }^{1}$
}

\begin{abstract}
It is widely believed that Islamic finance is inherently stable since the principle of risk-sharing and linking the financial to real counterpart in particular through its social finance are applied, hence the financial stability may successfully be attained. If mimicking the conventional finance, Islamic model will probably be facing instability, following the financial cycle. There has been a growing literature discussing credit cycle in mainstream perspective since 2008 global financial crash. However, it is quite rare to find study, in macro context, on credit cycles and the effectiveness of integrated Islamic commercial and social finance in achieving macroprudential objective: curtailing excessive credit. This study is designed to empirically examine the characteristics of cycles stemming from conventional and Islamic credit whether both have similar trend and also to investigate how the integrated Islamic commercial and social finance may be effective to hamper such cycles. By employing Hodrick-Presscot Filter, Markov Switching and Vector Error Correction Model, this study demonstrates that, in terms of cycle, Islamic model cycle has certain similarities with conventional counterpart since it functions under similar financial environment despite the fact that Islamic has less amplitude compared with conventional credit. Both credit and financing cycles tend to grow rapidly (excessive) several months before global financial crisis happened in 2008. This means that, in a dual banking system, credit and financing boom may precede financial crisis. Moreover, it is apparent also that the integrated Islamic finance is proven to be effective in curbing credit growth due to the effectiveness of both macroprudential instrument applied in banking sector and social finance in safeguarding financial stability.
\end{abstract}

Keywords: Credit cycle, Macroprudential policy, Markov Switching, HP filter

JEL Classification: E32, E51, G29

Received: September 18, 2017; Revised: January 17, 2018;

Accepted: February 3, 2018

1 Centre for Development of Islamic Economics and Philanthropy, Universitas Muhammadiyah Yogyakarta. Email: rifdoisme@gmail.com. 


\section{INTRODUCTION}

\subsection{Background}

There is a paradigm shift in the way many economists think about the stability of financial system. Before financial crisis happened in 2008, it was commonly believed that safeguarding financial stability was sufficient through maintaining price stability. Financial meltdown has changed radically such a policy paradigm in advanced and emerging countries. Since then, there have been growing literatures examining extensively the need for macroprudential policy in safeguarding financial stability. Unfortunately, researches on macroprudential policy and financial stability that focuses especially on Islamic finance are limited.

Islamic financial system, which is believed by many to be inherently stable, has also been in question whether this system is immune from financial imbalances since most of Islamic financial system is operated under dual banking system. While several studies on the effectiveness of macroprudential policy in a dual banking system have been conducted empirically, the study on credit cycle and the integrated Islamic commercial and financial aspects are still hard to find. As stated clearly by Ahmed et al. (2015), it is highly likely that Islamic social finance can be the main contributor to achieve sustainable development goals by mitigating the risk and reducing vulnerability of the poor.

Most of studies on the implementation of macroprudential policy in a dual banking system particularly in Indonesia are done separately from its interaction to Islamic social finance, i.e zakāh (alms giving) and infāq/shadaqah (charitable fund). Such an interaction, however, is essential in order to reach comprehensive conclusion, proving whether the integrated Islamic finance is stable from external shocks. Many studies on macroprudential policy implemented in Islamic banking, for instance, are undertaken by Ascarya et al. (2016c) and Zulkhibri and Satria (2017b). Study done by Ascarya et al. (2016c) was aimed at evaluating one instrument, namely financing-to-value (FTV) and loan-to-value ratios (LTV), whether the implementation of both is effective in dual banking system. This study concluded that both FTV and LTV are not sufficient for reducing Islamic home financing and conventional home loan, respectively. This means that Islamic social finance needs to be taken into consideration in constructing the model.

In contrast, the research conducted by Zulkhibri and Satria (2017b) that sought also to assess the effectiveness of loan-to-funding ratio based on reserve requirement (RR-LFR) as macroprudential instrument 
demonstrated the successful of reserve requirement at curtailing both financing and credit growth in Indonesian dual banking system. Furthermore, it is crucial nowadays to evaluate the impact of macroprudential instruments in particular when more than one instrument is applied.

This study is intended to fill these two gaps. It first identifies the characteristics of credit and financing boom in the banking sector functioning under dual banking system. In terms of methodology, this applies Markov Switching model to identify the states in which credit become excessive. Secondly, it seeks to investigate empirically the effect of interactions between macroprudential and monetary policy on credit/financing, especially when several macroprudential tools are applied.

The rest of the paper is organised as follows. Section 2 highlights the overview of related literatures on financial cycle and the effectiveness of macroprudential policies interaction. Section 3 describes the data and econometric techniques used in this paper. Section 4 discusses the empirical results and analyses. Finally, section 5 is conclusion.

\section{LITERATURE REVIEW}

\subsection{Related Studies on Credit Boom and Financial Cycle}

Since 2008 financial crisis, there has been a growing literature reexamining the relationship between financial and real sector of the economy. Unlike classical views which states there is no significant correlation between both of them in long term since the real sector depends greatly on factors of production, post-crisis paradigm is now attempting to shift the assumption on which pre-crisis analysis was based, arguing that recent crises stemmed from financial sector. In order to prove such a new hypothesis generated after 2008 global crisis, a rapidly growing literature seeks to assess whether the financial factors from total credit, credit-to-GDP ratio, property price and equity price could characterise financial cycle, which has been important tool through its boom and bust to analyse what main variable may bring about financial imbalances. There are studies exploring the correlation between credit growth, equity and house prices which tend to be the main variables in characterizing financial cycle, as conducted by Claessens et al. (2011a); Claessens et al. (2011b); Drehmann et al. (2012); Borio (2012); and Strohsal et al. (2015). 
Study by Claessens et al. (2011a) had an attempt to characterize financial cycle which is derived particularly from credit, house and equity prices. They try also to further identify what the main characteristics of financial cycles are (their duration and amplitude), how synchronized they are within and across the countries as well as when the coincidence of cycles results in a greater financial effect. Answering numerous questions arisen earlier, they use a large database with a long period of credit, house and equity prices that can further be employed to form the cycles for a large number of developed countries. This research is different from previous studies in threefold: first, compared to other works analyzing financial cycle, this study documents the main features of cycles through cross-country analysis covering the interactions between different cycles. Second, it employs the rigorous methodology for analyzing boom and bust financial cycles. Also, quarterly data is utilized to estimate cross-country analysis rather than annual data in order to achieve robust conclusion. Third, they also identify number of factors relating to the duration and amplitude of financial cycles.

The study highlights some key findings: it is found that the main features of financial cycles are: (1) downturns seem to be shorter (five to eight quarters) compared to upturns which tend to longer and slower; (2) credit cycles seem to be less profound and shorter than equity and house prices cycles; (3) there have been changes in the characteristics of cycles especially equity prices cycles which become much shorter. Furthermore, regarding the synchronization between cycles within and across countries, it is evident that financial cycle is correlated but not perfectly to each other within countries, in particular for credit and house price cycles while across the countries, credit and equity prices cycles tend to be highly synchronized and have been rising over time.

In attempt to broaden the understandings about the interactions between business cycles and financial cycles since rarely have the studies been pursued focusing on causal relation between real and financial sector during upturns and downturns of financial cycles, Claessens et al. (2011b) conduct also the research on this issue using large data of both advanced and emerging market economies. To form business cycles, real output is employed to be the main variable while there are three financial variables they use to characterize financial cycle, namely credit, housing prices and equity prices. This work relies on "traditional" definition of cycles as they argue that such a method has still been simple and effective methodology to investigate the turning points of the business and financial cycle. This 
work reveals that credit and house prices cycle are more synchronised with business cycle rather than the cyclical behavoiur of equity prices. In addition, the findings of this study also demonstrate that financial cycle appears to be longer and deeper than business cycle. The assessment of the interactions between both cycles identify: while the duration and amplitude of recessions accompanied by financial distress, especially downturn of house prices, seem to be longer and deeper, the rapid growth of credit and house prices tend to make recoveries much faster and stronger.

Drehmann et al. (2012) complements and extends the previous works which have made attempt to charaterise financial cycle and compare it with business cycle, employing wide range of financial variables such as credit, credit-to-GDP ratio, property prices, equity prices and an aggregate asset price index and combining two approaches-turning point analysis and frequency-based filters-in order to reach more robust and comprehensive conclusion. To obtain expected result, they seek to compare the short-term cycles with medium-term cycles; the former represents the business cycle whereas the later has been identified by previous researchers as frequency of financial cycle. Moreover, unlike many researchers who tended to analyse them individually, this study tries not only to consider invidual variables but also to examine combinations of all variables included. The results highlight seminal contributions to the discussion: first, the behavoiur of medium-term cycles in credit and propery prices is considered to be the main variables that can characterize the financial cycle yet the other two variables namely equity prices and an aggregate asset price do not perform adequately. Second, since the mid-1980s, the financial cycle whose length and amplitude exceed those of the business cycle identified as short-term cycle (around 8 years) has increased and lasted for around 16 years. Third, upturns of the financial cycle linked to the systemic financial crisis are performing an important role in well defining medium-term cycle.

Research conducted by Borio (2012), in general, can represent the definition of financial cycle, stating that financial cycle is the result of interaction among perceptions regarding value and risk, behaviour to risk and financial constraint. Borio concluded his research, figuring six main characteristics of financial cycle, those are: (1) The nearest indicator on financial cycle are credit and property price; (2) Financial cycle has lower frequency than business cycle; (3) The peak of financial cycle has a strong relation to financial crisis; (4) It can detect early risk of financial stress; (5) the length and amplitude of financial cycles are influenced by prevailing 
policy regime; (6) the determination of financial cycle relate to total financing of the economy.

Aikman et al. (2013) focus his research on credit cycle, which may bring about banking crises and they also attempt to recognize the distinction of credit cycles and real economy cycles, documenting mediumterm cycle and relating boom-and-bust credit cycle to banking crises. They employ four variables in this work: real GDP growth, real bank loan growth, real bank asset growth and real money aggregates. By using band-pass filter proposed by Christiano and Fitzgerald (2003), this research finds that credit-to-GDP growth has a strong relation with financial crisis; an increase in credit growth has always been accompanied by a rise of the probability of banking crises over the last century. Other empirical finding of this study identifies that the length and amplitude of financial cycles are distinct from those of the business cycles, as explained by Claessens et al. (2011b) and Drehman et al. (2012).

Strohsal et al. (2015) pursue the recent study demonstrating financial cycle but it differs from other works relating to the financial cycle in two ways. First, it seeks to estimate the financial variables by using univariate time series model, namely autoregressive moving average (ARMA). The result of that model will be used to calculate frequency domain which may have more advantages when compared to both frequency-based filter and turning point analysis: one of which is that while the data may be limited, it is still possible to investigate long cycles. Also, pre-specified rule and frequency range required by both frequency-based filter and turning point analysis are not needed when adopting this approach. Second, through statistical means of this method it is likely to examine the hypotheses associating with several characteristics of the cycle.

The key findings from this study demonstrate that the duration of financial cycle was about 7 years in 1980s and 1990 for Germany, which had been similar to its (business) cycle counterpart. Since 1985, however, the financial cycle had shifted dramatically from short-term to mediumterm phenomenon with the length of about 15 years. In term of amplitude, the statistical evidence of this work is consistent with the other previous works undertaken previously by Drehmann et al. (2012) and Borio (2014), explaining that financial cycles have larger amplitude than business cycles.

Turning to the studies which examine credit booms and financial cycle, there have been relatively small numbers of research financial which concern to charaterise financial cycle in Indonesia. 
One out of the studies was undertaken by Utari et al. (2012), aiming not to extensively investigate the financial cycle, but this work has contributed to determining the maximum limit of the credit expansion. If credit grows much higher than its maximum limit, it is more likely that excessive credit will produce disastrous effect on the real economy especially on financial stability. This study also seeks to explore several macroprudential policies-Reserve Requirement and Capital Buffer-, both of which will be examined in order to know whether they can control effectively the credit growth. Applying HP filter introduced by Hodrick and Prescott (HP) and Markov Switching VECM, this study attempts to draw robust conclusion. There are two main conclucions deived from this research: first, as described by HP filter approach, from 1997 to 2012 the growth in real credit had been in the long-term trend, albeit that expansoin exceeded the maximum threshold during the crisis. However, after crisis, credit-to-GDP ratio generally was in the long-term trend. The result also demonstrates there is cointegration among variables: real credit, real GDP, inflation rate and interest rate. In the long-term, affected negatively by interest rate and inflation, real credit is positively influenced by real output. Second, Reserve Requirement as macroprudential policy can still be effective in reducing the build-up of credit while capital Buffer does not statistically affect the credit, though it has negative coefficient as expected.

Following the steps pursued by Drehmann et al. (2012) who have been successful in characterizing financial cycle of advanced countries such as Britain and USA, Alamsyah et al. (2014) carry out an extensive research on constructing financial cycle of Indonesia, adopting data and methodology utilized by them. This work is designed to form financial cycle of Indonesia and to contribute positively to a rapidly growing literature in that issue which is considered relatively rare in Indonesia. Not only does they analyse data individually but also the combinations of data are examined by estimating the concordance index suggested by Harding and Pagan to consider co-movement among variables. There are several main conclucions we may obtain: first, it is evident that the duration of financial cycle, which lasts between 9 and 10 years, has been double the length of business cycle. Based on co-movement estimated using concordance index, financial cycle is constructed by employing credit and credit-to-GDP ratiofor both financial cycles whether that is formed through narrow or broad credit. More importantly, it is possible to adopt financial cycle to be the early warning indicators for crises or financial distress. Besides, it is interesting to note that the amplitude of global financial crisis 2008 is even greater than that of economic crisis in 1998. 
The last result of this study demonstrates that there is close correlation between house price and credit cycles since disruptions in one market may certainly have a contagion effect to others. When housing downturns coincide with financial crises, downturns tend to have deeper and longer episodes. The same phenomenon also occurs globally in credit and equity cycles when they are associated with financial disruptions.

\subsection{Macroprudential Policy: Effectiveness and Interactions with Monetary Policy}

There have been many studies evaluating the effectiveness of macroprudential policy in global context and its interaction with monetary policy such as Tovar et al. (2012) in Latin America; Claessens (2013a); Claesse ns (2013b) in 48 countries; Kim and Mehrota (2016) in Asia-Pacific regions; Lee et al. (2016) in selected Asian Countries; Gambacorta et al. (2017) in America regions; Altunbas et al. (2017) in 61 advanced and emerging market economies and Gómez et al. (2017) in Colombia.

Tovar et al. (2012) seek to empirically examine the effectiveness of Reserve requirements and other macroprudential instruments implemented in Latin American countries. The empirical model concerns only one systemic risk: the pro-cyclicality of bank credit growth. Applying both event analysis and dynamic panel VAR, Tovar et al. (2012) reveal that the effect of reserve requirement on curtailing credit growth is moderate and effective in the short period of time. Another result from this study finds that there has been complementary interactions between monetary and macroprudential policy in recent periods.

The primary objective of monetary policy is to achieve price stability while macroprudential policy is intended to accomplish financial stability. There may be a trade-off between both of them when they interact. Study done by Claessens (2013a) analyses the characteristics of both monetary and macroprudential policies in their interactions. Since the price stability as reflected in stable inflation does not guarantee full macroeconomic stability - it can be seen in a rapid growth of credit and asset prices-, it will be detrimental for the macroeconomic stability as whole and lead to materialization of systemic risk, amplifying considerable decline in output. Lesson learned from recent global financial crisis is the need to introduce new tools on which policy makers can rely to complement monetary policy, concerning macrofinancial risks. Macroprudential policies thus appear to be the candidate to meet the objective. These tools consist of countercyclical 
capital buffer, caps on loan-to-value (LTV) and debt-to-income (DTI) ratios and others that have been adopted by many countries. Consequently, there will be an interaction between monetary and macroprudential policy that can improve or even reduce the effectiveness of each other. Those negative impacts do not create a significant challenge to implement both policies in a perfect world when both policies can successfully accomplish their objectives.

Furthermore, Claessens et al. (2013b) utilize panel data regressions to investigate in depth the response of changes of roughly 2800 banks' $^{\prime}$ balance sheets in 48 countries from period 2000-2010 to macroprudential policies. They find that instruments used for borrowers e.g. caps on debtto-income and loan-to-value ratios and limits on foreign currency lending, prove quite able to reduce banking system vulnerabilities during the boom period. Countercyclical buffers (such as reserve requirements, profit distribution and dynamic provisioning), however, are also effective in mitigating excessive bank leverage and assets yet few macroprudential instruments can stop decreases in bad times. In addition, they suggest that instruments aimed at controlling real estate demand are proven to be effective in mitigating financial vulnerabilities since they can ascertain two important facts: first, real estate cycles are main feature of financial cycles which are essential in addressing systemic banking risks and second, limiting demand for credit can be able to prevent banking crash.

Kim and Mehrota (2016) seek to explore the impacts of both monetary and macroprudential policies on macroeconomic indicators (real GDP, price level and real credit growth extended to private sector) to guarantee financial stability in Asia-Pacific regions whose their central banks have also implemented inflation targeting framework. Employing structural panel vector autoregressions (VAR) which seem quite possible to prompt the response of macroeconomic indicators mentioned earlier to the shocks that have been generated from monetary and macroprudential policies, the important result indicates that monetary and macroprudential policies shocks have had a significantly negative effect on real credit growth, price level and real GDP. This means tighter macroprudential policies will probably reduce not only credit growth but also price level which is monetary policy objective. Such a result also occurs in monetary policy; when central bank increase interest rate it will somewhat decrease both price level and credit growth, achieving the objective of price and financial stability. During normal times, monetary and macroprudential policies may complement each other perfectly, enabling central bank to 
attain both financial and price stability. However, when the economy grows with low inflation and booming credit growth central bank will face tradeoff between implementing one tool (e.g. macroprudential policy to reduce crdit growth) and imposing two instruments together in different purpose which may lead to conflict between both policies.

Lee et al. (2016) attempt to investigate the effectiveness of several macroprudential tools to limit credit growth, leverage growth and housing price boom in selected Asian countries by employing the Qual VAR model. The main findings of this study indicate that macoprudential policies adopted by many countries in Asia are effective to safeguard financial stability. Moreover, it is evident that different types of macroprudential instruments, which depend mainly on domestic circumstances, are effective to address the risks. It is paramount for policy makers in developing Asia to correctly identify time-dimensional and cross-sectional risks that may arise during economic boom (peak) (Borio, 2010).

Using meta-analysis, Gambacorta et al. (2017) attempt to resume the results of a joint research conducted by eight central banks in the America region regarding the effectiveness of the macroprudential policy to dampen credit growth and its interactions with monetary policy. The results of this indicate that overall the macroprudential policies applied in sample countries can successfully curb the credit cycle in the short period of time (three months) yet the capital-based requirements take more period (a year) to affect negatively the credit growth. Furthermore, it will be more effective when monetary and macroprudential policy run in the same direction (complementary) rather than both push in the opposite direction (substitute).

Gómez et al. (2017) have recently pursued that research aiming at examining whether reserve requirement and dynamic provisioning scheme for commercial loans have been successful in tackling excessive credit growth in Columbia. Employing fixed-effect panel data model, they utilize rich dataset of Colombian banks covering period 2006-2009 when policy makers introduced many tools to address the build-up of systemic risks, which is considered uncovered. They demonstrate that the implementation of both measures to curb credit growth in Colombian banks has been effective yet the effects differ, depending mostly on characteristics of individual banks. As pointed by Gambacorta et al. (2017), when monetary and macoprudential policy are mutually reinforcing in the same direction, they can have moderating effects on credit growth. 
The purpose of the paper by Altunbas et al. (2017) is to evaluate the macroprudential policies in preventing bank risks, covering 3177 banks in 61 advanced and emerging economies. This study indicates that loan-tovalue ratios, reserve and currency requirements which have been implemented to curb the cycle can affect significantly bank risk. In addition, capital requirements adopted for promoting bank's resilience have also significant impact on bank risk. Yet, the effects tend to vary according to the balance sheet characteristics.

Turning to Indonesia, there are also many studies focusing on whether the implementation of macroprudential policies can dampen credit growth and concerning the feedback effect of its interactions with monetary policy. For example, Utari et al. (2012) investigate the optimal credit growth and the effectiveness of reserve requirement and capital buffer; Wimanda et al. (2012) examine numerous instruments that have been implemented as macroprudential policy; Agusman et al. (2012) focus on dynamic provisioning; and Pramono et al. (2015) investigate the countercyclical capital buffer (CCB) implementation

The study by Utari et al. (2012) has sought to assess the credit growth which does not exert adverse impact on financial stability as reflected in stable economic growth and banking resilience. By using Markov-Switching (MS) Univariate, MS Vector Error Correction Model and Dynamic Panel, this research has also evaluated critically the effectiveness of macroprudential polices implemented in Indonesia in particular Reserve Requirement and capital buffer. Analysing excessive credit growth, Utari et al. (2012) find that the aggregate of credit, generally, had been in its long-term trend from period January 1997 to Mei 2012, indicating the credit growth was stable. In contrast, there was a significant change in credit growth after 1998 economic crisis as the credit tends to slightly deviate from the threshold.

The key finding resulting from MS Univariate and MS VECM suggests that there are three regimes, which are low, normal and high regime, to calculate the real credit growth. In the normal regime, the upper thresholds for real credit growth are $17.39 \%$ (MS univariate) and $22.15 \%$ (obtained from MS VECM), explaining if the credit expands beyond given threshold, it may certainly affect the financial stability negatively. This study also indicates that there is co-integration between real GDP, credit growth, inflation and interest rate. In the long term, both interest rate and inflation affect negatively on credit growth whereas real GDP has a positive impact on it. Finally, the study concludes Reserve Requirement (RR) can be effective 
as macroprudential policy in reducing credit growth and yet variable capital buffer does not significantly impact on credit.

Wimanda et al. (2012) attempt to evaluate the effectiveness of macroprudential policies which have been implemented in Indonesia, namely reserve requirement (RR), reserve requirement plus loan-to-deposit ratio $(R R+L D R)$, one-month and six-month holding $(\mathrm{OMH}+\mathrm{SMH})$, net open position (NOP) and loan-to-value ratio (LTV). This study applies event analysis and VARX model in order to obtain the robust conclusion. This paper is also intended to explore the implementation of policy integration which basically consists of monetary policy and macroprudential policy operating in current financial system by employing Dynamic Stochastic General Equilibrium (DSGE).

The results of event analysis and VARX model indicate that both onemonth holding period $(\mathrm{OMH})$ and six-month holding period $(\mathrm{SMH})$, designed to reduce the volatility of funds in SBI and to minimize the negative impact of speculative capital inflow, are effective in decreasing the nominal exchange rate volatility. By looking at the result of event analysis and VARX, the same conclusion can also be drawn, showing the effectiveness of net open position in reducing the exchange rate volatility. Given the purpose of Loan-to-value (LTV) and Down Payment (DP), which seeks to effectively limit the credit extended for consumptive purposes such as property and vehicle, it is evident based on the event analysis that LTV and DP are effective instrument for curbing excessive credit growth. It has been commonly known one out of several macroprudential instruments to manage the liquidity risk is reserve requirement (RR). Not to mention, this instrument is now aimed at diminishing credit disbursement to specific sector. Unlike several macroprudential instruments described earlier, the effectiveness of reserve requirement is rather limited as the result of event analysis indicates that RR does not significantly hamper liquidity excess which is exacerbated by increasing capital inflow as reflected in open market operation that tends to rise gradually. The result of VARX model also suggests the same conclusion as event analysis, pointing to shock from RR only makes limited impact upon liquidity excess. Furthermore, simulation performed by DSGE model finds the integration model between monetary (to address output and inflation) and macroprudential policy (to diminish excessive credit), which supports Tinbergen principle.

Agusman et al. (2012) attempt to explore the pro-cyclicality of the dynamic provisioning that includes loan provisioning. This study applies Hodrick-Prescott (HP) filter to identify trend and cycle derived from credit. 
This study finds that there is a positive correlation between credit-both narrow and broad-and GDP growth. In addition, while the economy grows, non-performing loan and capital adequacy ratio decline. The opposite condition, however, will happen when the economy slows down: increasing both non-performing loans and CAR. This fact actually demonstrates the pro-cyclicality behavior in Indonesian banking.

After 2008 global financial crisis, Basel Committee on Banking Supervision (BCBS) had imposed a policy framework called BASEL III which is designed to strengthen stable financial institutions by promoting strong capital and liquidity. Countercyclical capital buffer (CCB) is one of the instruments proposed to mitigate systemic risks which stem from excessive credit through increasing credit cost during economic boom so that banks have more capital buffer to be used in the downturns (Pramono et al., 2015). This study aims to examine the effect of countercyclical capital buffer (CCB) on credit growth in Indonesia by applying General Method of Moments (GMM). The key finding of this study suggest CCB can produce negative effect on credit growth, meaning that CCB implementation can significantly limit credit growth.

\subsection{Previous Studies}

There are number of recent researches which attempt to either theoretically or empirically analyse the implementation of macroprudential policy-caps financing-to-value and reserve requirements—under dual banking system. Zulkhibri and Naiya (2016) emphasise that the macroprudential policy practices in several countries adopting dual banking system in which Islamic financial institutions have specific and different regulations compared to their conventional counterpart even though both institutions can operate together.

They argue that the implementation of macroprudential polices in particular countries with dual banking system tends to vary depending on current institutional framework, traditions and political consensus. Thus, there is several conceptual models developed by each country. Moreover, macroprudential policies implemented in conventional system have also been introduced in Islamic system due to the fact that Islamic financial institutions still operates within profit-based framework which depends largely upon mark-up techniques.

Moreover, Ascarya et al. (2016a) propose the concept for future macroprudential framework under a dual financial system by using gap 
analysis. This paper concerns two aspects associating with central bank: (1) its objective; (2) its role in future macroprudential framework and four aspects from macroprudential policy, including (1) objective of macroprudential policy; (2) scope; (3) instrument and (4) authority. From the side of the Central Bank, first of all, it will be important in the future that Central Bank not only has a single objective which is to maintain price stability but also it should have the mandate for enhancing financial stability. Therefore, in the country adopting dual financial system the mandate of the Central Bank should be extended: to build economic wellbeing with full employment and resilient growth and to promote social welfare through equitable income distribution and wealth. Secondly, the Central bank serves pivotal role as monetary system to maintain price stability and payment system authority to promote efficient and reliable payment system. Through macroprudential responsibility, the Central Bank has to accomplish financial stability objective since monetary policy alone may not be sufficient to fulfill that goal. In the future, the Central Bank should be given ultimate authority to implement macroprudential policy.

Turning to the macroprudential aspects, instrument of macroprudential policy, in the future, must create profound impact not only on financial sector (MC) but also on real sector (PT). In the context of dual financial system, this policy should encompass conventional and Islamic macroprudential. In addition, Financial System Stability Coordination Forum (FKSSK) has been established to carefully preserve financial stability, bringing together Bank Indonesia, Financial Services Authority, Indonesia Deposit Insurance Corporation and Ministry of Finance to emphasise macroprudential and financial stability issues. This forum has currently been chaired, since its establishment, by Minister of finance, but it would be appropriate that in the future this forum will be chaired by Governor of Bank Indonesia.

Since the Islamic financial system is operated within dual financial system, Islamic banking may not be stable. As explained by many scholars, pro-cyclicality was defined as the fluctuations of financial variables that tend to follow economic cycle; when the real economy expands rapidly until reaching a peak of the cycle, this will probably cause the credit boom which can be followed then by economic bust and financial crash. Furthermore, procyclicality has resulted not only from the interactions between financial and business cycle but also from risk-taking behavior characterised by overoptimism during economic boom that encourages economic agents to aggressively invest their money in high-risk assets. Hence, it is crucial to 
examine the pro-cyclicality in the banking system due to its negative impact on financial system as a whole. Research by Ascarya et al. (2016b) tries to empirically analyse pro-cyclicality behavior of Islamic and conventional banking credit in Indonesia by employing several econometric methods, namely Ordinary Least Square (OLS), Autoregressive Distributed Lag (ARDL) and Error Correction Model (ECM). The key finding of this study suggest that Islamic banking financing is more procyclical than conventional counterpart.

It is apparent from the models that an increase in financing is caused mostly by real GDP growth as the coefficients of real GDP was much higher (almost twice) in Islamic model compared to conventional counterpart. Both financing and credit disbursed by Islamic and conventional bank are thus procyclical following economic cycle yet the pro-cyclicality of financing seems to be good procyclicality based on Granger causality because it does not create credit bubbles and therefore does not trigger financial instability. This result is in agreement with the principle of Islamic economics which links the Islamic banking to the real sectors through riba prohibition, profitand-loss sharing implementation. However, procyclicality of conventional credit may trigger financial crash since the loan does create bubbles and bring about build-up of systemic risk.

Other empirical study by Ascarya et al. (2016c) who use some econometric estimations to evaluate the effectiveness of macroprudential instruments (FTV and LTV) to curtail credit growth under Dual Banking System in Indonesia that the implementation of Financing-to-value and loan-to-value ratios is not effective to limit the Islamic home financing and conventional home loan, respectively. Furthermore, while FTV does not have negative impact to control non-performing home financing, LTV contributes to rising non-performing home loan.

The most recent study about the implementation of macroprudential policy in dual banking system was done systematically by Zulkhibri and Sakti (2017b). The purpose of that study is to examine empirically whether loanto-funding ratio based reserve requirements (RR-LFR) that has been applied in conventional and Islamic banks as a macroprudential instrument, is effective in curtailing credit and financing growth in dual banking system. Using generalized method of moments (GMM), they employ bank-level data of both conventional and Islamic banks covering the period 20012015. The key findings of this study demonstrate that the implementation of RR-LFR in Islamic banks is effective to reduce Islamic bank financing as it is shown by the negative coefficients of RR-LFR in all GMM estimations. 
They also find the same result in conventional model, showing that RR-LFR has a negative and significant impacts on credit growth yet the magnitude of this effect is somewhat higher than that of Islamic banks.

\subsection{Conceptual Framework}

In a dual banking system in which conventional and Islamic banks are operated together, it is necessary to test the cycles formed by both credit and financing since total credit has been considered as a main indicator of cycle. It is also essential to find whether, in dual banking system, financial crisis was preceded by excessive credit.

In order to achieve financial stability in this system, this paper will assess effectiveness of both macroprudential and monetary policy in addressing credit growth-after identifying its features (cycles). Then, the macroprudential instruments adopted in conventional system and monetary policy are included in the model to be empirically tested. Based on this result, it will be possible to design the comprehensive framework in dual banking system aimed at safeguarding financial stability.

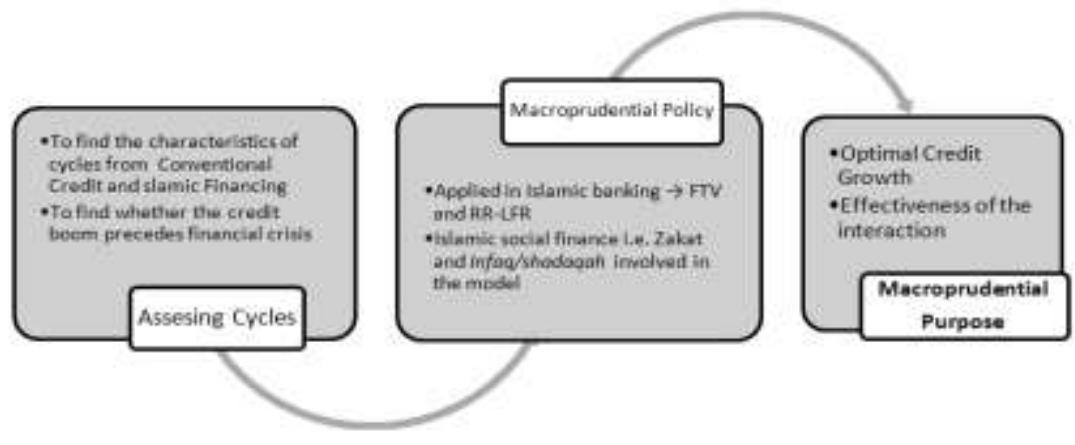

Figure 1.

Conceptual Framework

\section{METHODOLOGY}

\subsection{Data}

This study applies quantitative methods, namely Hodrick-Prescott (HP) Filter, Markov Switching (MS) Model and Vector Auto-regressions (VAR), which needs time series data. The quantitative data needed by those three approaches are monthly basis spanning from January 2004 to April 2017 obtained from several resources, such as Biro Pusat Statistik (BPS), 
Indonesian Economic and Finance Statistics of Bank Indonesia (SEKI-BI), Syariah Banking Statistics of Bank Indonesia (SPS-BI), and Banking Statistics of Bank Indonesia (SPI-BI).

\subsection{Method or Estimation Techniques}

\subsubsection{Hodrick-Prescott (HP) Filter}

One out of the methods used by previous researchers to estimate the cyclical component of the data is HP filter. This method was proposed by Hodrick and Prescott (1997) for investigating empirically postwar the United States economy (referred as business cycle) using quarterly data. There are previous studies that also utilize this method to examine the behavior of the financial variables such as Utari et al. (2012) who had sought to investigate the credit growth in Indonesia; Drehmann et al. (2010) uses this filter to calculate the credit-to-GDP gap; Ito et al. (2014) trying to create new financial activities indexes to be the early warning system for financial imbalances in Japan and Surjaningsih et al. (2014) who attempted to develop the early warning indictors for risk liquidity in Indonesia. Following Utari et al. (2012), this paper also applies this method to identify credit/financing cycle from conventional and Islamic banks in Indonesia.

HP filter has been commonly applied in economic research due to its flexibility in separating the data series to be two components: trend (gt) and gap or cycle (ct). Hence, a given time series yt is the sum of trend component (gt) and cyclical component (ct) that can be written as follow (Hodrick and Prescott, 1997):

$y_{t}=g_{t}+c_{t}$ for $t=1, \ldots \ldots, T$.

HP Filter approach separates cyclical component by minimizing the loss function referred as two-side HP filter (Utari, et al., 2012; Hodrick and Prescott, 1997):

$\operatorname{Min}\left\{\sum_{t=1}^{T} c_{t}^{2}+\lambda \sum_{t=1}^{T}\left[\left(g_{t}-g_{t-1}\right)-\left(g_{t-1}-g_{t-2}\right)\right]^{2}\right\}$

$\left\{g_{t}\right)_{t=-1}^{T}$

The parameter $\lambda$ is a positive number which controls the fluctuations in the growth series. Therefore, the larger the value of $\lambda$, the smoother the series will be. If $\lambda$ is equal to zero, trend component, thus, is the same as actual data $\left(g_{t}=y_{t}\right)$.. Conversely, if the value of $\lambda$ is infinite $(\lambda \rightarrow \infty)$, the trend will be convergent to a linear time trend with $g_{t}=\beta * t$. Hodrick and Prescott (1997) suggest that $\lambda$ for quarterly data is 1600 as it has commonly used for identifying business cycle. Based on Surjaningsih et al. (2014), this 
paper uses $\lambda=14400$ for monthly data as it was suggested by consensus among researchers, describing for yearly basis the value of $\lambda=100$ and $\lambda=$ 1600 for quarterly.

Furthermore, determining the extent to which the indicator (real credit and financing) deviate from its trend is essential to investigate the degree of either excessive or overcooling in credit and financing based on movement of the indicator. The gap between actual data and their trends can be calculated:

gap $=x_{i}-x_{i}^{t}$

where $x i$ is the actual value of indicator in month $_{i}$ and $x_{i}^{t}$ is the trend of

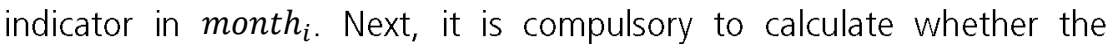
indicator exceeds the thresholds by first calculating the standard deviation of gap $(\sigma)$ :

$\sigma=\sqrt{\frac{1}{N-1}} \sum_{i=1}^{n}\left(x_{i}-x_{i}^{t}\right)^{2}$

To determine the thresholds can be calculated as follow:

Lower threshold $=x_{i}^{t}-k \sigma$

Upper threshold $=x_{i}^{t}+k \sigma$

Both thresholds are useful for identifying when excessive (modest) credit and financing occur. Therefore, the thresholds employed for the value of $k$ in this paper are 1 and 1.75 .

Table 1.

Data used for HP filter

\begin{tabular}{lcl}
\hline \multicolumn{1}{c}{ Data } & Source & \multicolumn{1}{c}{ Period } \\
\hline Real Total Credit (in natural log scale) & SPI-BI & January 2004-April 2017 \\
Real Credit for Working capital & SPI-BI & January 2004-April 2017 \\
Real Credit for Investment & SPI-BI & January 2004-April 2017 \\
Real credit for Consumption & SPI-BI & January 2004-April 2017 \\
Real Total Financing (in natural log & SPS-BI & January 2004-April 2017 \\
scale) & & \\
Real Financing for Working capital & SPS-BI & June 2006-April 2017 \\
Real Financing for Investment & SPS-BI & June 2006-April 2017 \\
Real Financing for Consumption & SPS-BI & June 2006-April 2017 \\
\hline
\end{tabular}




\subsubsection{Markov Switching Model}

This study also employs univariate model, known as Markov Switching (MS) model, in order to empirically investigate when boom-and-bust credit and financing tend to occur. By this model, it is possible to use one dependent variable (univariate) as a main variable. Since this study is intended to assess credit cycle, the variables utilized are credit gap (for conventional loan) and financing gap (Islamic financing).

This method, as pointed by Hamilton (1989), is alternative approach to popular linear stationary model, assuming that first different of data series may follow non-linear process rather than linear process. The nonlinearity of this model relies mostly on shifts in regime or episodes that can determine the variability of the series if the data fluctuate across the regime. In addition to this, Simorangkir (2012) stated that by employing Markov-Switching (MS) approach, there are several advantages that need to be taken into consideration: (1) assumption made in this method is that there are two states in the economy: normal state and crisis state. Both states cannot be directly analysed unless we utilise indicators of these states to be observed through monitoring their behaviors. This model enables researchers to differentiate normal state from crisis state as the latter tends to experience considerable fluctuation compared to the former and thus the value of upcoming state will be determined by current state; (2) MS permits using dependent variable; (3) this approach can identify the duration of crisis period and (4) MS may be adopted for analysing nonlinear behaviour as explained extensively by Hamilton.

There have been many studies which apply this model to either analyse business cycle or other financial issues. For instance, Hamilton (1989), who proposed this approach, had conducted study which tried to characterize the business cycle for the United States; Utari et al. (2012) employing this model to determine the optimal credit growth in Indonesia; and Simorangkir (2012) identified bank runs in Indonesia during 1998 crisis and found that this model contained error prediction merely between $0.69 \%$ and $2.08 \%$. However, this method is rather rare to be applied in Islamic economics researches hence this paper will adopt this method to assess the excessive credit/financing in a dual banking system.

Following Hamilton (1989), Markov-Switching that has fourth-order auto-regression with, MS-AR(4) one of two constant, $\mu_{-} 1$ or $\mu \_2$ :

$$
\begin{aligned}
& \left(y_{t-} \mu_{s_{t}}\right)=\varphi_{1}\left(\left(y_{t-} \mu_{s_{t-1}}\right)+\varphi_{2}\left(\left(y_{t-} \mu_{s_{t-2}}\right)+\varphi_{3}\left(\left(y_{t-} \mu_{s_{t-3}}\right)+\right.\right.\right. \\
& \varphi_{4}\left(\left(y_{t-} \mu_{s_{t-4}}\right)+\varepsilon_{t}\right.
\end{aligned}
$$


Where: $\varepsilon_{-}(t) \sim N(0, \sigma \wedge 2)$. From that model, it can rewritten the model MS with no autoregressive lag, MS-AR(P) with $p=0$ and switch in mean and variance as follows:

$y_{t}=\mu_{s_{t}}+\varepsilon_{t}$, where $\varepsilon_{t} \sim N\left(0, \sigma_{s t}^{2}\right)$

where $\mu_{-}\left(s_{-} t\right)=\mu \_1 \quad s_{-} 1 t+\mu \_2 s_{-} 2 t$ and $\sigma \_s t \wedge 2=\sigma_{-} 1 \wedge 2 s_{-}(1 t$ )$+\sigma_{-} 2^{\wedge} 2 s_{-}(2 t)$, so the distribution function for equation (3.8) can be written in equation (3.9) as follows,

$$
p\left(y_{t} \mid Z_{t} ; \theta\right)=\frac{1}{\sqrt{2 \pi \sigma_{a_{t}}}} \exp \left\{-\frac{\left(y_{t}-\mu_{s_{t}}\right)^{2}}{2 \sigma_{s t}^{2}}\right\}
$$

Moreover, the transition between states is governed by a Markov chain whose realizations take on values in $\{1, \ldots, K\}$ :

$p\left(s_{t}=j \mid s_{t-1}=i\right)=p_{i j}$

with,

$\sum_{j=1}^{K} p_{i j}=1$ for $i=1, \ldots, K$

The equation (3.10) used in Hamilton (1989) can rewritten in new equation that consider there are three states in the model (3.12):

$$
\begin{aligned}
& p\left(s_{t}=1 \mid s_{t-1}=1\right)=p_{11,} \\
& p\left(s_{t}=2 \mid s_{t-1}=1\right)=p_{12,} \\
& p\left(s_{t}=3 \mid s_{t-1}=1\right)=p_{13,} \\
& p\left(s_{t}=1 \mid s_{t-1}=2\right)=p_{21,} \\
& p\left(s_{t}=2 \mid s_{t-1}=3\right)=p_{22,} \\
& p\left(s_{t}=3 \mid s_{t-1}=3\right)=p_{23},
\end{aligned}
$$

Data used in Markov Switching model are the real credit gap and real financing gap covering the period January 2004 to April 2017. In this section, this paper seeks to compare the results obtained from MS with the Indonesian financial cycle that was characterized by Alamsyah et al. (2014) whether there is the same result and cycles that follow financial cycle.

\subsubsection{Vector Autoregressive (VAR) Model}

In this research, vector auto regressive (VAR) model that has been adopted by previous researchers to empirically examine the interactions between monetary and macroprudential policy implemented is used. Kim and 
Mehrota (2016) used this model to analyse the implementation of macroprudential instrument in the Asia Pacific countries adopting inflation target framework. Previously, VAR model was also employed by Tovar et al. (2012) for the same objective as this study has. If there is co-integration among variables, this model can be transformed into vector error correction model. In order to find whether variables are co-integrated in the long term, this study applies Johansen co-integration test.

VAR is used to analyze the dynamic impact of the surprise factor contained in the system variables. The general VAR model according to Enders (2010: 298) can be represented as follows,

$$
x_{t}=\mu_{t}+\sum_{i=1}^{k} A_{i} X_{t-1}+\varepsilon_{t}
$$

Where $x t$ is a vector of endogenous variables with $(n \times 1)$ dimension, $\mu t$ is a vector of exogenous variables, including constant (intercept) and trend, Ai is coefficient matrix with $(n \times n)$ dimension, and $\varepsilon t$ is a vector of residuals. In a simple bivariate system $y_{t}$ and $z_{t}, y_{t}$ is affected by current and past value of $z t$, while $z t$ is affected by current and past value of yt. If there is cointegration among variables in the model presented below, it is possible to adopt VECM that can be mathematically represented as follows (Achsani et al., 2005).

$$
\Delta x_{t}=\mu_{t}+\prod x_{t-1}+\sum_{i=1}^{k-1} \Gamma_{i} \Delta x_{t-i}+\varepsilon_{t}
$$

Where, $\Pi$ and $\Gamma$ are functions of Ai. The matrix $\Pi$ can be decomposed into two matrices $\lambda$ and $\beta$ with ( $n \times r)$ dimension. $\Pi=\lambda \beta T$, where $\lambda$ is called an adjustment matrix and $\beta$ is a cointegration vector. Moreover, $r$ is a cointegration rank.

There are two models adopted in this study: first model is limited only for Islamic commercial instruments and the second model will encompass Islamic macroprudential instruments and Islamic social finance aspects e.g. zakah and infaq/shadaqah. Therefore, the equation (3.16) can be rewritten by entering Model I:

$$
x_{k}=x_{k}=[\ln r t f, \operatorname{lng}, \text { inf }, \mathrm{ftv}, \mathrm{rr}, \pi]
$$


$\left[\begin{array}{c}\Delta \operatorname{lnrtf}_{t} \\ \Delta \operatorname{lng}_{t} \\ \Delta \inf _{t} \\ \Delta f t v_{t} \\ \Delta r r i b_{t} \\ \Delta \pi_{t}\end{array}\right]=\left[\begin{array}{c}\alpha_{10} \\ \alpha_{20} \\ \alpha_{30} \\ \alpha_{40} \\ \alpha_{50} \\ \alpha_{60}\end{array}\right]+\left[\begin{array}{ccccccc}\alpha_{11} & \alpha_{12} & \alpha_{13} & \alpha_{14} & \alpha_{15} & \alpha_{16} & \alpha_{17} \\ \alpha_{21} & \alpha_{22} & \alpha_{23} & \alpha_{24} & \alpha_{25} & \alpha_{26} & \alpha_{27} \\ \alpha_{31} & \alpha_{32} & \alpha_{33} & \alpha_{34} & \alpha_{35} & \alpha_{36} & \alpha_{37} \\ \alpha_{41} & \alpha_{42} & \alpha_{43} & \alpha_{44} & \alpha_{45} & \alpha_{46} & \alpha_{47} \\ \alpha_{51} & \alpha_{52} & \alpha_{53} & \alpha_{54} & \alpha_{55} & \alpha_{56} & \alpha_{57} \\ \alpha_{61} & \alpha_{62} & \alpha_{63} & \alpha_{64} & \alpha_{65} & \alpha_{66} & \alpha_{67}\end{array}\right]\left[\begin{array}{c}\Delta \ln r t f_{t-i} \\ \Delta \operatorname{lng} g_{t-i} \\ \Delta i n f_{t-i} \\ \Delta f t v_{t-i} \\ \Delta r r i b_{t-i} \\ \Delta \pi_{t-i}\end{array}\right]+\left[\begin{array}{c}\varepsilon_{1 t} \\ \varepsilon_{2 t} \\ \varepsilon_{3 t} \\ \varepsilon_{4 t} \\ \varepsilon_{5 t} \\ \varepsilon_{6 t}\end{array}\right]$ (3.14)

Model II in which zakat and infaq/shadaah are included:

$$
x_{k}=[\text { Inrtf, Ing, inf, Itv, rr, } Z, s]
$$

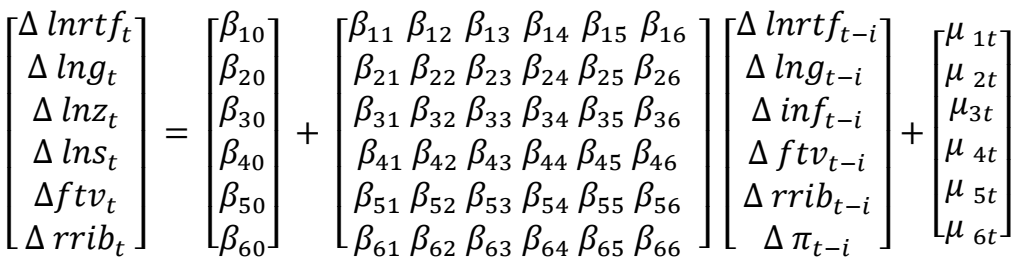
(3.15)

where, $\Delta$ is the change of variable from previous period; $\alpha, \beta$ are constant of the variables; $t_{-i}$ is the lag operator of the variables and $\varepsilon, \mu$ are error term. Following Sims (1980), it is possible to include dummy variables in the model as he used the data for Germany and US.

Table 2

Data used for VAR model

\begin{tabular}{|c|c|c|c|}
\hline Data & Symbol & Period & Source \\
\hline $\begin{array}{l}\text { Industrial Production Index } \\
\text { (IPI) (log scale) }\end{array}$ & $\ln g$ & January 2005-April 2017 & BPS \\
\hline CPI inflation (\%) & inf & January 2005-April 2017 & BPS \\
\hline Policy rate (\%) & $\pi$ & January 2005-April 2017 & SEKI-BI \\
\hline $\begin{array}{l}\text { Real Total Financing (log } \\
\text { Scale) }\end{array}$ & $\ln r t f$ & June 2006-April 2017 & SPS-BI \\
\hline Financing-to-value (dummy) & $f t v$ & June 2006-April 2017 & $\mathrm{BI}$ \\
\hline Reserve requirement IB & rrib & June 2006-April 2017 & SPS-BI \\
\hline Zakat & $z$ & $\begin{array}{l}\text { January 2011-February } \\
2017\end{array}$ & BAZNAS \\
\hline shadaqah & $s$ & $\begin{array}{l}\text { January 2011-February } \\
2017\end{array}$ & BAZNAS \\
\hline
\end{tabular}




\section{RESULT AND FINDING}

\subsection{The Results of Constructing Cycles}

\subsubsection{HP Filter Results}

This section provides the resuls of the filtering process which will be divided into two parts: first part contains the results of conventional real loan (aggregate) and type of usage for which the credit was extended (working capital, investment and consumption). Second part explains the results of Islamic financing model.

From four figures below (1), it can be seen that the results of HP filter reveal when conventional credit tends to grow rapidly across the thresholds that have been determined before, namely 1 standard deviation and 1.75 standard deviation for both upper and lower thresholds. Black vertical line in the figures denotes the stress event (2008 global financial crisis), while the shaded red area depicts the period when conventional credit was becoming excessive. Cycles as the results of the deviation of actual credit from its trend show the fluctuations in conventional credit.
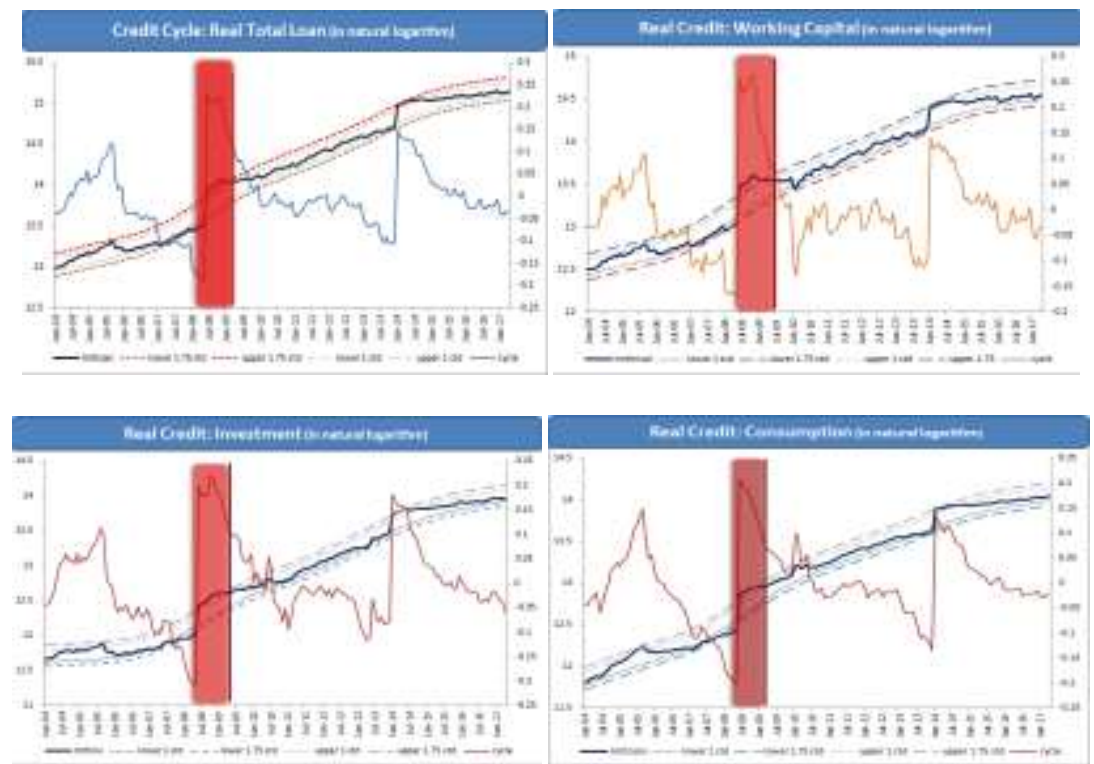

Figure 2.

Long-term trend and cycles for Conventional Model

There are main findings that need to be taken into account: first, aggregate real total loan increased significantly across the upper thresholds of both $1 \mathrm{std}$. and $1.75 \mathrm{std}$. in January 2008 before the crises happened in 
the late of 2008, and hence the other types of credit, based on usage, also experienced the same condition. Second, looking at the cycles formed it is possible to identify that in 2005 there was a considerable decline in conventional credit until it hit the lowest point in the end of 2007, showing the effect of mini crisis on credit that happened during period 2005. This can be seen from the deviation of actual real loan from the lower thresholds in December 2007. Third, as predicted by Alamsyah et al. (2014), the Indonesian financial cycle would have reached a peak in 2013 Q3 and the cycle of aggregate conventional loan seems to follow that pattern, surging tremendously in 2013.

Moreover, according to study conducted by Dell'Ariccia et al. (2012) credit booms could lead to financial crises and had also happened before banking crises. Aikman et al. (2013) also stressed that the boom episodes of the credit cycles are identical with large deviations of credit from the trend and hence, excessive credit has been highly correlated with banking crises. Given that the conventional loan saw an excessive growth it may be accompanied by financial crisis as many previous researchers has extensively explained, the result of this study is in line with Drehmann et al. (2013) who found that total credit gap and bank gap are effective to be early warning indicators for banking crises.

Turning to the real Islamic financing cycles in figures (2) below, the aggregate real financing and other types of financing cycles saw a considerable rise in five months prior to the 2008 financial crisis. At the same time, actual financing (blue line) also exceeded the upper thresholds $(1.75 \mathrm{std})$ in all types of financing. That means there is an excessive financing growth several months before crisis. 

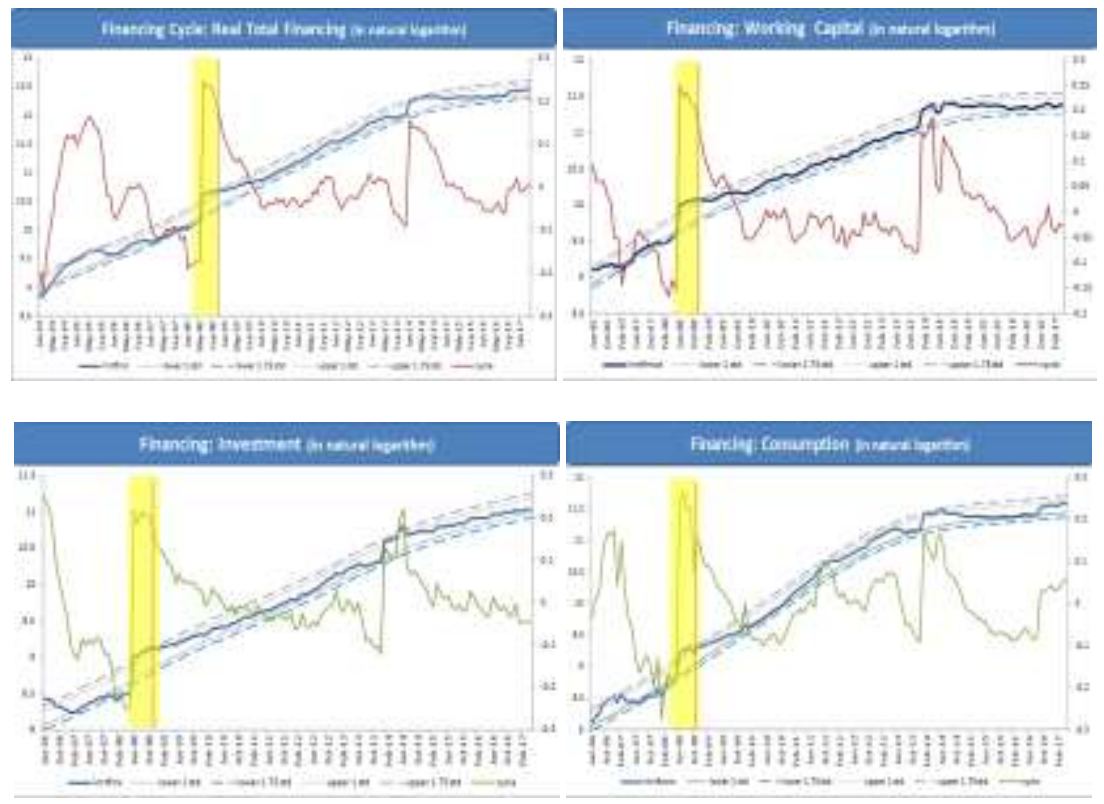

Figure 3.

Islamic Financing Long-trend and cycles

Islamic financing in dual system has also the same results as conventional counterpart, yet the there is still a slight difference between both of them: given the fact that financing cycle tends to deviate from the upper thresholds, its deviation is much stable rather than conventional (see figure 2). That indicates the stability of Islamic financing that has been relied heavily on real sector eventhough it does not mean that financing is immune from financial crisis since it functions in a dual banking system. In 2005 Islamic financing had experienced significant decline, however in 2013 it seemed to grow rapidly across the threshold. This might happen since the Islamic banks are operated in a dual banking system in which Islamic financial system is likely to deviate from the Shari'a norms and thus it may not be stable from shocks or financial imbalances (Zulkhibri and Sakti, 2017a). As pointed out by Zulkhibri and Naiya (2016), there is no noticeable difference between both, in part because the Islamic system is still far from ideal and mostly based on mark-up profit. Hence, it is urgently needed to implement macroprudential policy in Islamic financial system due to the fact that it has also been applying similar system as conventional, for instance fractional reserve banking and fiat money that can probably trigger financial imbalances in the whole financial system. 


\subsubsection{Markov Switching Results}

The result of Markov Switching model is divided into two: conventional credit and Islamic financing. MS (univariate) model can demonstrate when the credit/financing booms in three regimes (states) selected. Credit boom can be identified when the series shift markedly through the probability value; if the value reaches well under 1.0 (probability), the excessive credit has strong probability to occur. The model used for conventional credit is MS-AR(0). Table 3 given summarizes the periods in three states when excessive credit (conventional banks) may likely to happen from the period January 2004 to April 2017.
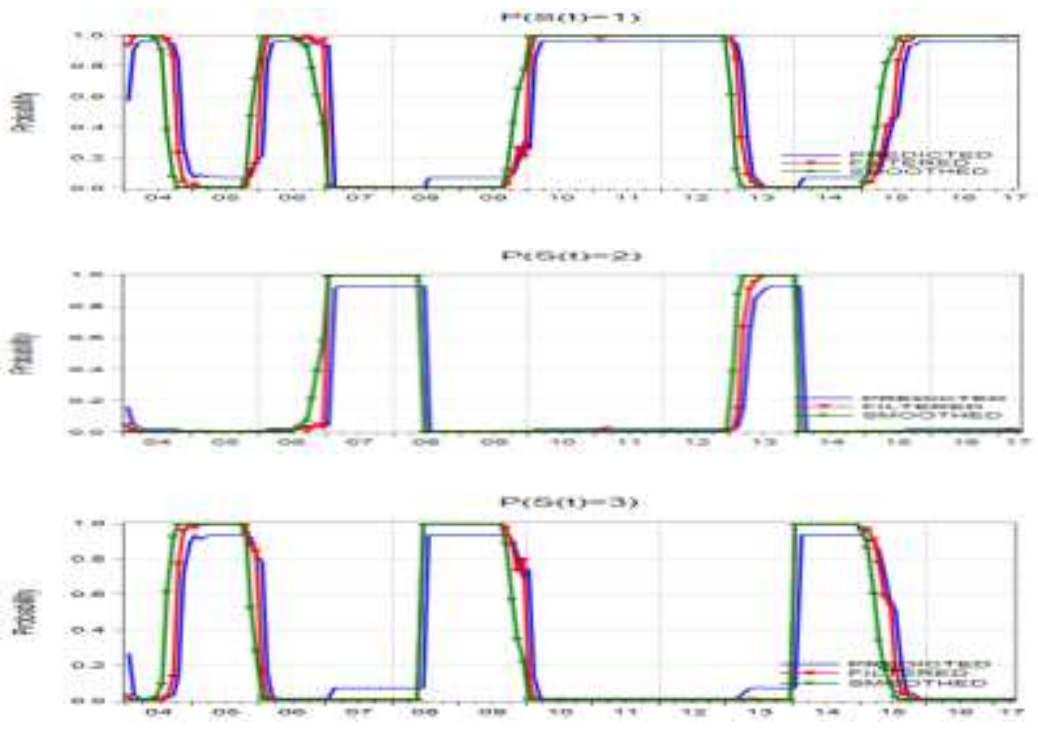

Figure 4.

Regimes of Conventional credit

Table 3.

MS Regimes

\begin{tabular}{lll}
\hline \multicolumn{1}{c}{ Regime 1 P(S(t)=1 } & \multicolumn{1}{c}{ Regime 2 P(S(t)=2 } & \multicolumn{1}{c}{ Regime 3 P(S(t)=3 } \\
\hline March-August 2004 & November 2006-July & October 2004-October \\
January-December 2006 & 2008 & 2005 \\
January 2010-February & June-December 2013 & May 2008-September 2009 \\
2013 & & January 2014-February 2015 \\
October 2015-April 2017 & & \\
\hline
\end{tabular}

From the table (3) above, it is likely to compare the result from MS model to the actual credit boom and financial disruptions that significantly 
affected Indonesian economy and its financial system (Alamsyah et al., 2014): period 2005.Q3-2006.Q1 and 2008.Q4-2009Q4. Regime 1 and 3 detect the credit boom before the period of mini economic crisis in 2005.Q3, meaning that credit boom preceded financial imbalance as stated already by Dell"Ariccia et al. (2012). Regime 2 also reveals a significant probability in July 2008 (starting from November 2006) just before 2008.Q4 crisis happened, when credit boom, in this regime, had ended. The result of regime 2 is in line with the Indonesian financial cycle which peaks at the end of December 2013 (see Alamsyah et al., 2014; Bank Indonesia, 2015 and 2016). Moreover, using this approach is useful to calculate the optimal growth of credit. By looking at the regime statistics (see appendix), this paper can estimate that the optimal credit growth is $18.4 \%$ percent. This growth is obtained from the low regime, as displayed in its mean. Therefore, that can be the threshold for credit growth; if credit grows around this threshold, it will be beneficial for real economy vise versa.

Furthermore, the model applied for financing is also MS-AR(0) with three states from it can be seen the period when financing grows significantly. While there are three states in this model yet the regime (1) tends to perform better the other two regimes, reaching 1.0 probability consistently.
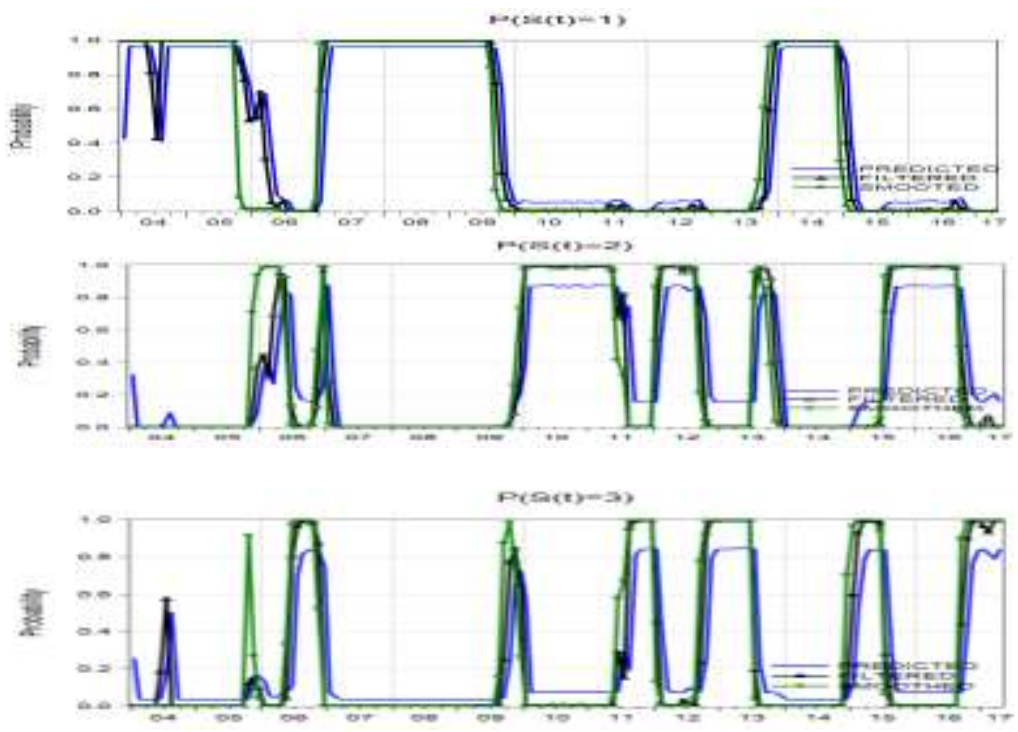

Figure 5

Regimes of Islamic financing 
Table 4.

MS Regimes

\begin{tabular}{lll}
\multicolumn{1}{c}{ Regime 1 $\mathrm{P}(\mathrm{S}(\mathrm{t})=1$} & \multicolumn{1}{c}{ Regime 2 $\mathrm{P}(\mathrm{S}(\mathrm{t})=\mathbf{2}$} & \multicolumn{1}{c}{ Regime $\mathbf{3}(\mathrm{S}(\mathrm{t})=\mathbf{3}$} \\
\hline June 2004-September & January 2006-July 2006 & October 2005 \\
2005 & January 2010-May 2011 & June -December 2006 \\
March 2007-Agustus 2009 & January-August 2012 & November 2009 \\
December 2013-December & August 2013 & May 2011-December 2011 \\
$\mathbf{2 0 1 4}$ & June 2015-November & August 2012-June 2013 \\
& 2016 & January 2015-May 2015 \\
\hline
\end{tabular}

Such results are evident in table (4), almost financing cycle in regime (1) precedes both mini crisis in 2005.Q3 and financial crisis 2008.Q4, while regime (3) demonstrate the boom in 2005.Q4 but the probability value does not reach the 1.0. Even though this model is highly volatile, this method indicates that Islamic financing is highly likely to grow rapidly before the crisis. It may be argued that when Islamic financial system is operated under dual banking system, it is undeniable that this system may certainly follow the conventional counterpart. The financing growth also follows Indonesian financial cycle of the whole system, rising in the same direction as it can be seen in 2013 when financial cycle was predicted to reach a peak, Islamic financing tends to increase (see regime 3, June 2013). Consequently, Islamic financial system operated in dual banking system is still not totally immune from financial imbalances, as stressed by Ascarya et al. (2016c). Optimal financing growth generated from this model is $25 \%$.

\subsection{VAR results}

Before discussing the results of Vector Autoregressions, there are several tests that need to be fulfilled. First, stationary test to detect the existence of unit root, for this objective Augmented Dickey-Fuller test (ADF test) with $5 \%$ McKinnon critical value is used. The data will be stationary if the value of ADF is less than critical value $(5 \%)$. The results, as reported in the appendix $2 \mathrm{a}$, show that all variables in this model are stationary at first difference. Second, optimal lag selection to avoid autocorrelation problem. Following Sims (1980), Islamic model I, applies 8 (eight) lags as optimal lag length. Third, stability test aimed at testing whether this model is stable in its optimal lag length to obtain valid results of Impulse Response Function (IRF) and Forecast Error Variance Decomposition (FEVD). The results reveal the stability of the model as modulus (unit circle) is inside the circle (see appendix 2b). 
Turning to the second model, in terms of optimum lag, 4 (four) is chosen to be the optimal lag according to Final prediction error (FPE) and sequential modified LR. This model shows its stability, as presented from unit circle that does not deviate from the circles. Moreover, it is apparent also that second model has co-integration among variables, meaning there is long term relation. Hence, it can be concluded that this model can apply vector error correction model (see appendix 2c).

\subsubsection{Islamic Model I (Commercial Aspect)}

Figure 7 depicts the results of Islamic financing model. Overall, it is evident that the response of financing to numerous shocks may likely to be similar with conventional counterpart. First, the response of financing to economic growth (GDP) is positive. This means financing is also highly pro-cyclical. However, as pointed out by Ascarya et al. (2016b), the pro-cyclicality of financing seems to be good procyclicality as it does not create credit bubbles and therefore does not trigger financial instability. This result is in agreement with the principle of Islamic economics which links the Islamic banking to the real sectors through riba prohibition, profit-and-loss sharing implementation. This result is in line with previous study done by Ascarya et al. (2016b). Second, the contractionary policy rate has negative effect on financing. This indicates, in the dual banking system, when central bank rises the policy rate it can significantly reduce financing growth since Islamic banks function in the similar financial environment with conventional.
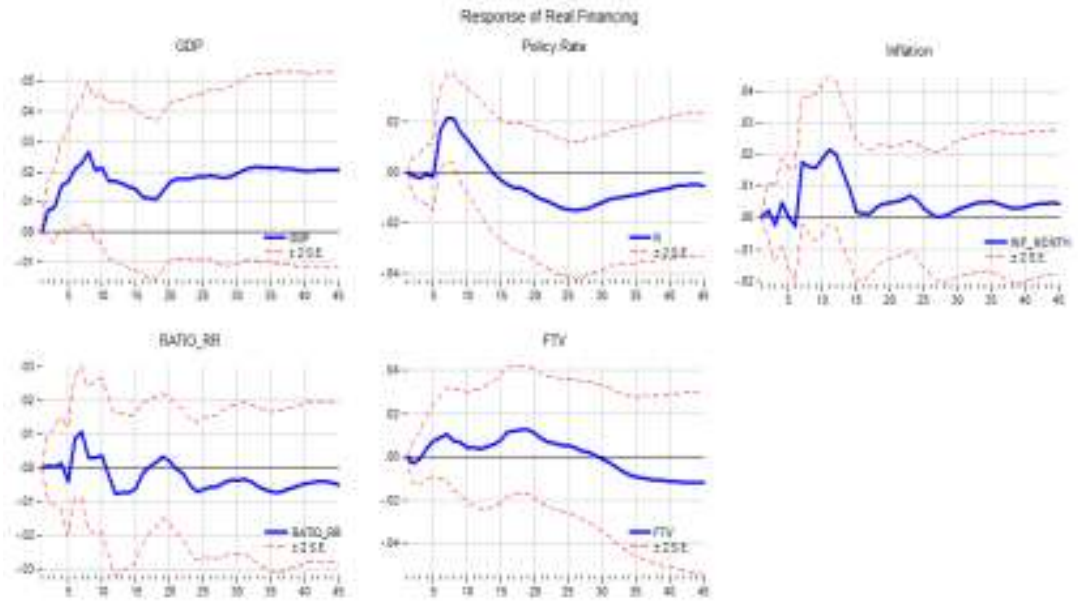

Figure 7.

Impulse Response Function of Islamic model I 
Macroprudential tools that has been implemented in Indonesian Islamic bank are Financing-to-deposit ratio (FTV) (Ascraya et al. 2016c) and loan-to-funding deposit based on reserve requirement (Zulkhibri and Sakti, 2017b). This study attempts to broaden the research through combining both instruments and policy rate in one model in order to identify the interaction between them more comprehensively. Overall, it is evident that RR has been successful in limiting financing growth, whereas financing-tovalue ratio becomes effective in 3-year horizon. The effectiveness of RR in this result strengthens the previous study undertaken by Zulkhibri and Sakti (2017b) who arrived at the same conclusion, explaining that RR effect on financing is less than on conventional credit. Such a result also can be seen from table 6 below, which describe the response of financing to RR shock is relatively smaller about 1.5 to 1.7 percent compared to conventional model (see table 5).

Table 6.

Response of Financing to Macroprudential and Monetary Shocks

\begin{tabular}{lcccc}
\hline Shocks & 2 Year & 3 Year & 4 Year \\
\hline GDP & 1 Year & & & \\
FTV & $19.6 \%$ & $20.4 \%$ & $21.9 \%$ & $22.7 \%$ \\
RR & $2.17 \%$ & $4.38 \%$ & $3.45 \%$ & $4.44 \%$ \\
Policy rate & $1.57 \%$ & $1.7 \%$ & $1.72 \%$ & $1.67 \%$ \\
Inflation & $9.17 \%$ & $8.11 \%$ & $8.42 \%$ & $6.92 \%$ \\
\hline
\end{tabular}

FTV contributes significantly to dampen financing at 4-year horizon which is about 4.4 percent. If compared to policy rate, FTV impact is somewhat less than policy rate. Therefore, policy rate has the largest impact on reducing financing growth. Finally, it can be argued based on aforementioned results that the interactions between macroprudential policy (Islamic) is proven to be successful in reducing Islamic bank financing.

\subsubsection{Islamic Model II (Integrated Commercial and Social)}

This model attempts to encompass macroprudential instruments as adopted commonly in commercial domain and social instruments. Figure 8 below reveals that this model has several similarities compared with previous one, indicating the model is consistent and does not contradict each other. GDP in this model has contributed significantly to increase the 
real financing growth, and yet reserve requirement seems to be the effective tool in curtailing financing growth, as pointed out already by Zulkhibri and Sakti (2017b). In addition, FTV shock does not have a significant impact on controlling financing since it has high volatility of shock. This result is in line with what was concluded in the previous study conducted by Ascraya et al. (2016c), stating that the implementation of FTV for limiting Islamic home financing was not sufficient, even though FTV does not induce non-performing-financing unlike LTV counterpart.
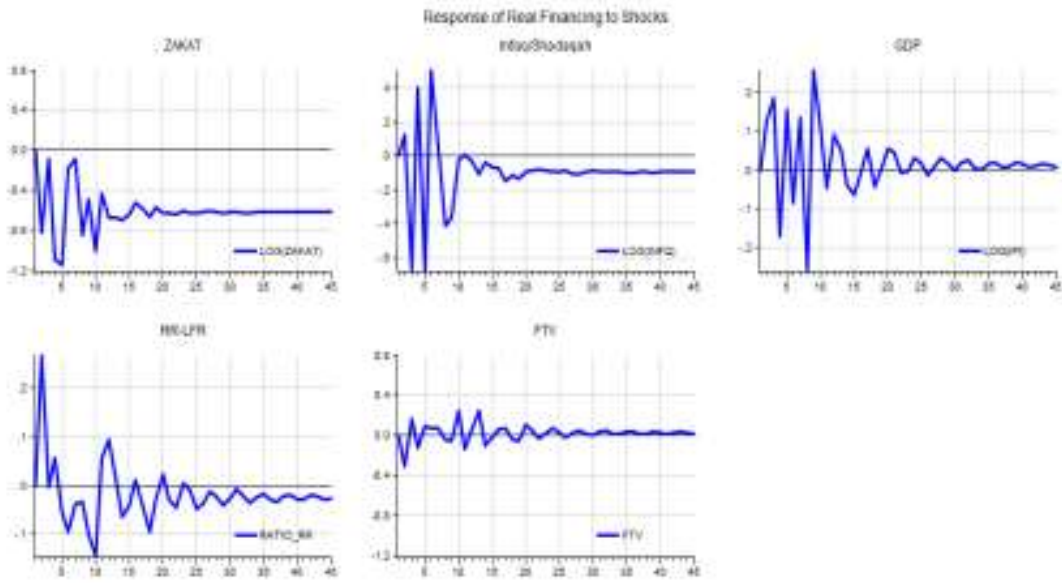

Figure 8.

Impulse Response Function for Integrated model

In regard with the Islamic social finance, it is interesting to note that both zakah (alms giving) and shodaqah (charitable fund) have a considerable effect-compared to other macroprudential instruments from commercial counterpart-on curbing the excessive growth of financing that may trigger financial imbalances since Islamic financing is operated under dual banking system. Zakat has the largest contribution to reduce the financing growth, followed by charitable fund. This result is in agreement with Ahmed et al. (2015) stating that zakat collected can be the main contributor for mitigating the risk that results from the crisis (recession). It can be clearly seen from the table t below, showing that the largest contributor for curbing credit cycle, and more broadly financial imbalance, is zakah by well under 15 per cent. By adopting this integrated model of Islamic finance, the pro-cyclicality of Islamic banking financing can be controlled, plummeting tremendously from roughly 22 per cent in Model I to around 0.35 per cent. 
Table 7

Response of Financing to integrated Islamic finance

\begin{tabular}{lcccc}
\hline \multicolumn{1}{c}{ Horizons } & 1 Year & 2 Year & 3 Year & 4 Year \\
& & & & \\
\hline GDP & $0.61 \%$ & $0.40 \%$ & $0.28 \%$ & $0.23 \%$ \\
Zakah & $12.83 \%$ & $13.9 \%$ & $14.3 \%$ & $14.47 \%$ \\
Infaq/shadaqah & $3.54 \%$ & $2.3 \%$ & $1.74 \%$ & $1.50 \%$ \\
FIV & $0.52 \%$ & $0.44 \%$ & $0.32 \%$ & $0.27 \%$ \\
RR-LFR & $0.29 \%$ & $0.2 \%$ & $0.15 \%$ & $0.13 \%$ \\
\hline
\end{tabular}

Source: author's calculation

That result is supporting what Agus D.W. Martowardojo (2016) stated clearly in his speech, saying:

"Zakat funds can become a buffer as well as economic stabilizer. On the macroeconomic level, proportion of zakat linked with income functions as an automatic stabilizer; when aggregate income increases (boom period), more zakat can collected and more amount remains as the disposal of government to allocate as transfer payments. Thus, zakat enables the distributive allocation works independently and help stabilize the extreme business cycle."

\section{CONCLUSION}

From the results of HP filter, it can be concluded that both conventional credit and Islamic bank financing has certain similarities in the characteristics of cycles. Both cycles tend to deviate from upper thresholds-excessive credit-several months before global financial crisis happened in 2008. This means that, in a dual banking system, credit and financing boom may precede financial crisis. The results of Markov Switching model strengthen filtering result, suggesting that credit/financing boom was likely to happen before the period of mini economic crisis in 2005.Q3 and also in July 2008 just before 2008.Q4 crisis happened. This means that credit boom preceded financial imbalance.

Impulse Response Function results for Islamic model I show that credit is highly pro-cyclical. Compared to integrated Islamic model, the procyclicality of Islamic financing can be reduced tremendously meaning that by integrating commercial and social aspect of Islamic finance can be very effective in curbing the credit cycle and hence in attaining macroprudential objective. However, reserve requirement share can be effective to reduce credit growth in both models. Social aspects of Islamic finance play an 
important role since they can act as an automatic stabilizer when economy booms (bust); couple with an excessive growth in financing.

From the results of this study, there are two recommendations that need to be taken into consideration: it is undeniable the social finance can be contributor of achieving macroprudential policy, hence the government and Central Bank have to issue a different macroprudential policy that may cover both commercial and social aspect of Islamic finance. Second, it is highly recommended that Islamic bank can play its role in Social finance as stated in Islamic banking Act No. 21/2008 ch. 2 article no. 4 by establishing its own baitul maal. 


\section{REFERENCES}

Achsani, Noer Azam, Oliver Holtemoller, and Hizir Sofyan. (2005). Econometric and Fuzzy Modeling of Indonesian Money Demand. In Pavel Cizek, Wolfgang Hardle, and Rafal Weron (eds.), Statistical Tools for Finance and Insurance (pp. 249-270). Berlin Heidelberg, Germany: Springer-Verlag.

Agung, Juda, Solikin M Juhro, Harmanta and Tarsidin. (2016). Managing Monetary and Financial Stability in a Dynamic Global Environment: Bank Indonesia's Policy Perspectives (BIS Papers No 88).

Agusman, Gunadi I, Setiyono B, Yumanita D and Hafidz J. (2012). Dynamic Provisioning: The Case of Indonesia (Working Paper WP/15/2012). Jakarta: Bank Indonesia.

Ahmed, Habib, Mohieldin, M, Verbeek, J and Aboulmagd, F. (2015). On the Sustainable Development Goals and the Role of Islamic Finance. (Working Paper WPS 7266). World Bank.

Aikman, D., A. G. Haldane and B. D. Nelson. (2013). Curbing the Credit Growth. The Economic Journal, 12(1), 1-38.

Alamsyah, Halim, J. Adamanti, Diana Yumanita, and R. I. Astuti. (2014). Siklus Keuangan Indonesia (Working Paper WP/8/2014). Jakarta: Bank Indonesia.

Altunbas Y, Binici M and Gambacorta L. (2017). Macroprudential Policy and Bank Risk (BIS Working Papers No 646).

Ascarya, Karim AA, Rahmawati S, Muqorobin M and Wiranatakususma DB. (2016a). Conceptual Proposal for Future Macroprudential Policy Under a Dual Financial System in Indonesia. In M. Zulkhibri et al. (eds.). Macroprudential Regulation and Policy for the Islamic Financial Industry (pp. 35-53). Switzerland: Springer International Publishing.

Ascarya, Rahmawati S and Karim AA. (2016b). Testing of the Procyclicality of Islamic and Conventional Banks in Indonesia. In M. Zulkhibri et al. (eds.). Macroprudential Regulation and Policy for the Islamic Financial Industry (pp. 133-152). Switzerland: Springer International Publishing. 
Ascraya, Rahmawati S and Karim AA. (2016c). Effectiveness of LTV/FTV as Macroprudential Instrument under Dual Banking System in Indonesia. Paper presented at 11th International Conference on Islamic Economics and Finance organized by IIUM, IRTI-Islamic Development Bank and International Association of Islamic Economics. Kuala Lumpur, Malaysia, October 11-13.

Bianchi J. (2010). Credit Externalities: Macroeconomic Effects and Policy Implications. American Economic Review, 10C(2), 398-402.

Borio, Claudio. (2012). The Financial Cycle and Macroeconomics: What Have We Learnt? (BIS Working Papers No 395).

Cerutti E, Claessens S and Laeven L. (2015). The Use and Effectiveness of Macroprudential Policies: New Evidence (IMF Working Paper WP/15/61).

Claessens S, Ghosh SR and Mihet R. (2013). Macroprudential Policies to Mitigate Financial System Vulnerabilities. Journal of International Money and Finance, 3S, 153-185.

Claessens S, Kose MA and Terrones ME. (2011a). Financial Cycle: What? How? When? (IMF Working Paper WP/11/76).

Claessens S, Kose MA and Terrones ME. (2011b). How Do Business and Financial Cycles Interact? (IMF Working Paper WP/11/88).

Claessens S. (2013). Interactions between Monetary and Macrprudential Policies in an Interconnected World. Paper prepared for IEA-BCU Roundtable on Capital Flows, Capital Controls and Monetary Policy, Montevideo.

Claessens S. (2014). An Overview of Macroprudential Policy Tools. (IMF Working Paper WP/14/214).

Collin M, Druant M and Ferrari S. (2014). Macroprudential Policy in the Banking Sector: Framework and Instrument. NBB Financial Stability Review, 85-97.

Craig, R. S., E. P. Davis and A. G. Pascual. (2006). Sources of Procyclicality in East Asian Financial Systems. Hong Kong Institute for Monetary Research and Cass Business School.

Dell'Ariccia G, Igan D, Laeven L and Tong H. (2012). Policies for Macrofinancial Stability: How to Deal with Credit Booms. (IMF Staff Discussion Note SDN/12/06). 
Drehmann M, Borio C, Gambacorta L, Jimenez G and Trucharte C. (2010). Countercyclical Capital Buffers: Exploring Options (BIS Working Papers No 317).

Drehmann, M. (2013). Total Credit as An Early Warning Indicator for Systemic Banking Crises (BIS Quarterly Review June).

Drehmann, M., C. Borio and K. Tsatsaronis. (2012). Characterising the financial cycle: don't lose sight of the medium term!. (BIS Working Papers No 380).

Enders, Walter. (2010). Applied Econometric Time Series. (3rd Edition). Hoboken: John Wiley \& Sons, Inc.

Galati $G$ and Moessner R. (2014). What Do We Know about The Effects of Macroprudential Policy? (DNB Working Paper No 440).

Gambacorta L and Murcia A. (2017). The Impact of Macroprudential Policies and Their Interaction with Monetary Policy: An Empirical Analysis using Credit Registry Data (BIS Working Papers No 636).

Gómez E, Lizarazo A, Mendoza JC and Murcia A. (2017). Evaluating the Impact of Macroprudential Policies on Credit Growth in Columbia. (BIS Working Paper No 634).

Hamilton JD. (1989). A New Approach to the Economic Analysis of Nonstationary Time Series and the Business Cycle. Econometrica, 57(2), 357-384.

Hamilton JD. (1990). Analysis of Time Series Subject to Changes in Regime. Journal of Econometrics 45, 39-70.

Harun, C. A., Taruna, A. A., Nattan, R. R., and Surjaningsih, N. (2014). Financial Cycle of Indonesia-Potential Forward Looking Analysis. (Working Paper WP/9/2014). Jakarta: Bank Indonesia.

Hayek. F. A. (2008). Prices and Production and other Works: F.A. Hayek on Money, The Business Cycle, and Gold Standard. Edited by Joseph T. Salerno. Auburn, Alabama: Ludwig von Mises Institute.

Hodrick RJ and Prescott E. (1997). Postwar U.S. Business Cycles: An Empirical Investigation. Journal of Money, Credit and Banking, 2S(1), $1-16$.

Ito $Y$, Kitamura T, Nakamura K and Nakazawa T. (2014). New Financial Activity Indexes: Early Warning System for Financial Imbalances in Japan (Bank of Japan Working Paper Series No 14-E-7). 
Jeong, Hyung-Kwon. (2009). The Procyclicality of Bank Lending and Its Funding Structure: The Case of Korea. Paper prepared for 2009 BOK International Conference "The Credit Crisis: Theoretical Perspectives and Policy Implicatons.

Kim S and Mehrota A. (2016). Effects of Monetary and Macroprudential Policies-Evidence from Inflation Targeting Economies in the AsiaPacific Region and Potential Implications for China (Global Unit Research Working Paper No 2016-025).

Kim, Soyoung and Aaron Mehrotra. (2015). Managing Price and Financial Stability objectives-What can we learn from the Asia-Pacific Region? (BIS Working Papers No 53).

Kim, Soyoung and Aaron Mehrotra. (2016). Maintaining Price and Financial Stability by Monetary and Macroprudential Policy (BIS Papers No 88).

Lee M, Asuncion RC and Kim J. (2016). Effectiveness of Macroprudential Policies in Developing Asia: An Empirical Analysis. Emerging Market Finance and Trade, 52(4), 923-937.

Martowardojo, Agus D.W. (2016). Integrating Islamic Commercial and Social Finance to Strengthen Financial System Stability. Keynote speech delivered at International Seminar and the 2nd JIMF Call for Papers, Surabaya-Indonesia, 27-28 October 2016.

Nurzaman, M. S. (2016). Evaluating the Impact of Productive based Zakat in the Perspective of Human Development Index: A Comparative Analysis. Kyoto Bulletin of Islamic Area Studies 9, 42-62.

Pramono B, Hafidz J, Adamanti J, Muhajir MH, Alim MS. (2015). The Impact of Countercyclical Capital Buffer Policy Towards Credit Growth in Indonesia (Working Paper WP/4/2015). Jakarta: Bank Indonesia.

Sims, Christopher A. (1980). Macroeconomics and Reality. Econometrica, $48(1), 1-48$.

Simorangkir I. (2012). Study on Early Warning Indicators of Bank Runs in Indonesia: Markov-Switching Approach (Working Paper WP/01/2012). Jakarta: Bank Indonesia.

Strohsal T, Proano CR, Wolters J. (2015). Characterizing the Financial Cycle: Evidence from a Frequency Domain Analysis (Discussion Paper Deutsche Bundesbank No 22). 
Surjaningsih N, Yumanita D and Deriantino E. (2014). Early Warning Indicators for Banking Liquidity Risk (Working Paper WP/1/2014). Jakarta: Bank Indonesia.

Tovar CE, Garcia-Escribano M and Martin MV. (2012). Credit Growth and the Effectiveness of Reserve Requirements and Other Macroprudential Instruments in Latin America (IMF Working Paper WP/12/142).

Utari GAD, Arimurti T and Kurniati IN. (2012). Optimal Credit Growth and Macroprudential Policy to Curb the Credit (Working Paper WP/12/2012). Jakarta: Bank Indonesia.

Warjiyo, Perry. (2014). The Transmission Mechanism and Policy Responses to Global Monetary Developments: the Indonesian Experience (BIS Papers No 78).

Warjiyo, Perry. (2016). Central Bank Policy Mix: Key Concepts and Indonesia's Experience. Bulletin of Monetary, Economics and Banking, 18(4), 380-407.

Wimanda RE, Permata MI, Bathaludin MB, Wibowo WA. (2012). Study on Macroprudential Policy Implementation in Indonesia: Evaluation and Analysis of Integrated Policy of Bank Indonesia. (Working Paper WP/11/2012). Jakarta: Bank Indonesia.

Zulkhibri M and Naiya I. (2016). Macroprudential Policy and Regulation in a Dual Banking System: An Exploratory Perspective. In M. Zulkhibri et al. (eds.). Macroprudential Regulation and Policy for the Islamic Financial Industry (pp. 3-24). Switzerland: Springer International Publishing.

Zulkhibri M and Sakti MRP. (2017a). Macroprudential Policy and Tools in Dual Banking System: Insights from Islamic Finance Literature. (Working Paper Series WP/2017/04). Jeddah: IRTI.

Zulkhibri M and Sakti MRP. (2017b). Macroprudential Policy and Financing Behaviour in Dual Banking System: Bank-Level Evidence from Indonesia (Working Paper Series WP/2017/05). Jeddah: IRTI. 


\section{APPENDIX I}

\section{Markov Switching}

\section{a. Conventional model (Actual and Fitted)}

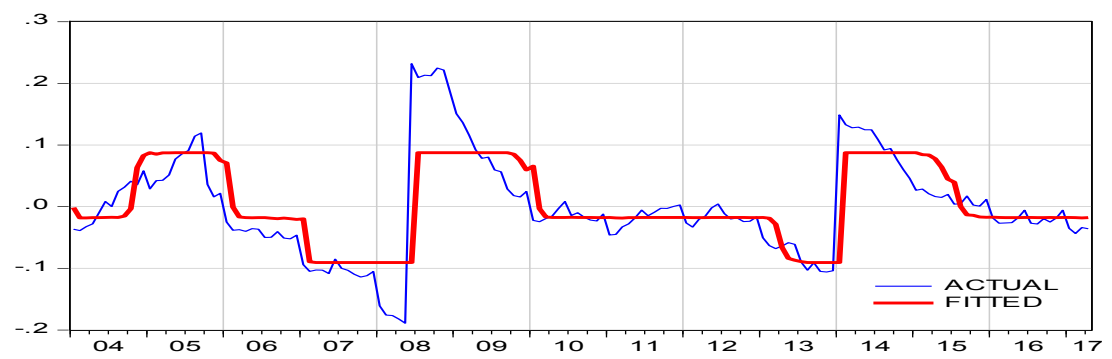

Regime Specifications

\begin{tabular}{|c|c|c|c|}
\hline $\begin{array}{l}\text { Transition } \\
\text { Probabilities }\end{array}$ & Regime 1 & Regime 2 & Regime 3 \\
\hline 1 & 0.968194 & 0.020547 & 0.011259 \\
\hline 2 & 0.00 & 0.927240 & 0.072760 \\
\hline 3 & 0.068556 & 0.00 & 0.931444 \\
\hline \multicolumn{4}{|c|}{ Expected Duration } \\
\hline & 31.44015 & 13.74378 & 14.58657 \\
\hline \multicolumn{4}{|c|}{ Output Coefficients } \\
\hline & Regime 1 & Regime 2 & Regime 3 \\
\hline Coefficient & -0.017108 & -0.105311 & 0.095339 \\
\hline Std error & 0.003347 & 0.008410 & 0.012528 \\
\hline z-Statistic & -5.111076 & -12.52150 & 7.610154 \\
\hline Mean & 0.517 & 0.184 & 0.297 \\
\hline
\end{tabular}

b. Islamic Model ((Actual and Fitted)

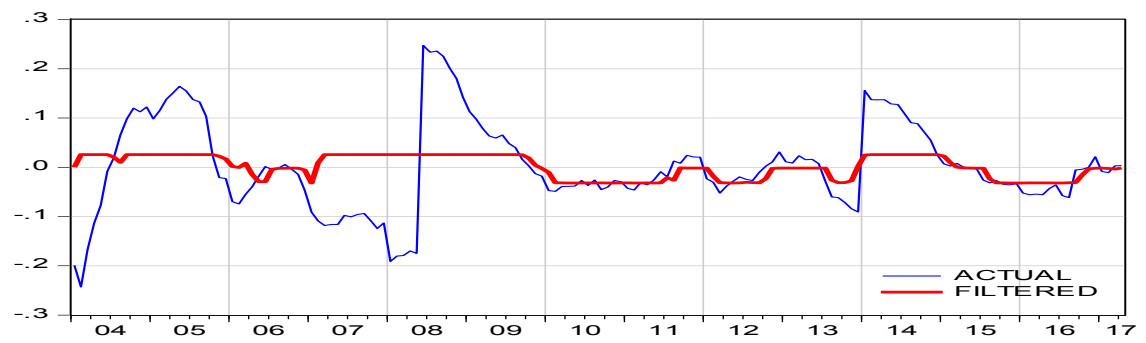




\section{Regime Specifications}

\begin{tabular}{|c|c|c|c|}
\hline $\begin{array}{l}\text { Transition } \\
\text { Probabilities }\end{array}$ & Regime 1 & Regime 2 & Regime 3 \\
\hline 1 & 0.962990 & 0.00 & 0.037010 \\
\hline 2 & 0.048508 & 0.877590 & 0.073902 \\
\hline 3 & 0.00 & 0.156890 & 0.843110 \\
\hline \multicolumn{4}{|c|}{ Expected Duration } \\
\hline & 27.01996 & 8.169248 & 6.373900 \\
\hline \multicolumn{4}{|c|}{ Output Coefficients } \\
\hline & Regime 1 & Regime 2 & Regime 3 \\
\hline Coefficient & 0.026476 & -0.038656 & 0.005262 \\
\hline Std error & 0.016607 & 0.002565 & 0.002605 \\
\hline z-Statistic & 1.594280 & -15.06792 & 2.019769 \\
\hline Mean & 0.421 & 0.323 & 0.255 \\
\hline
\end{tabular}

\section{VAR Model}

\section{a. ADF test summary (Islamic Model I and II)}

\begin{tabular}{lllll}
\hline \multirow{2}{*}{ Variable } & \multicolumn{2}{c}{ ADF Value } & \multicolumn{2}{l}{ MacKinnon Critical Value (5\%) } \\
\cline { 2 - 5 } & Level & $1^{\text {st }}$ Difference & Level & $1^{\text {st }}$ Difference \\
\hline IPI & -3.091589 & -5.967617 & -2.900137 & -2.900670 \\
Inf & -8.692576 & -11.34499 & -2.883930 & -2.884477 \\
$\pi$ & -1.872014 & -9.124398 & -2.884109 & -2.883930 \\
rtf & 0.589594 & -11.17851 & -2.883753 & -2.883930 \\
ftv & -0.896847 & -11.35782 & -2.883753 & -2.883930 \\
rr & -7.302600 & -3.834982 & -2.884291 & -2.886074 \\
z & 1.291466 & -11.81423 & -2.886290 & -2.886290 \\
S & -1.391826 & -8.387966 & -2.885249 & -2.885249 \\
\hline
\end{tabular}

b. VAR Stability for Model I (left) and Model II (right)
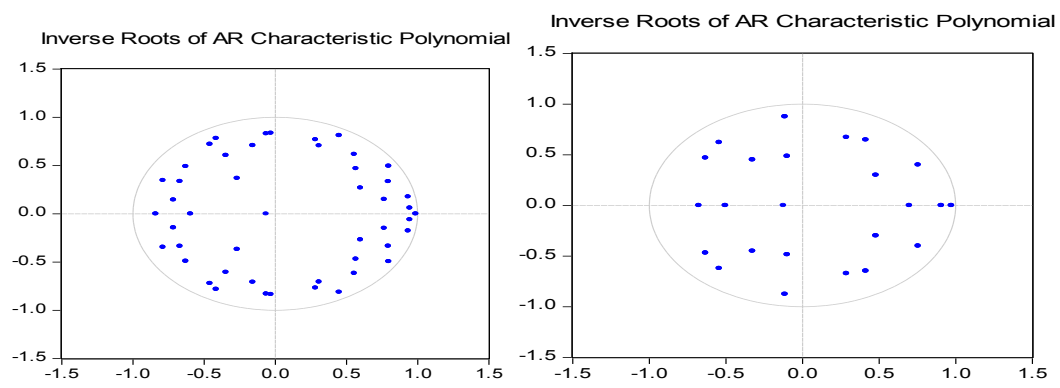


\section{c. Johansen Cointegration test for Model II}

Unrestricted Cointegration Rank Test (Trace)

\begin{tabular}{lllll}
\hline \hline $\begin{array}{l}\text { Hypothesized } \\
\text { No. of CE(s) }\end{array}$ & Eigenvalue & $\begin{array}{l}\text { Trace } \\
\text { Statistic }\end{array}$ & $\begin{array}{l}\text { 0.05 } \\
\text { Critical Value }\end{array}$ & Prob. ** \\
\hline \hline None * & 0.512113 & 141.2354 & 103.8473 & 0.0000 \\
At most 1 * & 0.346825 & 91.71597 & 76.97277 & 0.0024 \\
At most 2 * & 0.318675 & 62.32820 & 54.07904 & 0.0077 \\
At most 3 * & 0.267715 & 35.85185 & 35.19275 & 0.0424 \\
At most 4 & 0.115903 & 14.35248 & 20.26184 & 0.2659 \\
At most 5 & 0.081321 & 5.852492 & 9.164546 & 0.2024 \\
\hline \hline
\end{tabular}

Trace test indicates 4 cointegrating eqn(s) at the 0.05 level

* denotes rejection of the hypothesis at the 0.05 level

**MacKinnon-Haug-Michelis (1999) p-values

Unrestricted Cointegration Rank Test (Maximum Eigenvalue)

\begin{tabular}{lllll}
\hline \hline $\begin{array}{l}\text { Hypothesized } \\
\text { No. of CE(s) }\end{array}$ & Eigenvalue & $\begin{array}{l}\text { Max-Eigen } \\
\text { Statistic }\end{array}$ & $\begin{array}{l}0.05 \\
\text { Critical Value }\end{array}$ & Prob. ** $^{*}$ \\
\hline \hline None * & 0.512113 & $\mathbf{4 9 . 5 1 9 3 9}$ & $\mathbf{4 0 . 9 5 6 8 0}$ & 0.0043 \\
At most 1 & 0.346825 & 29.38777 & 34.80587 & 0.1924 \\
At most 2 & 0.318675 & 26.47635 & 28.58808 & 0.0908 \\
At most 3 & 0.267715 & 21.49937 & 22.29962 & 0.0644 \\
At most 4 & 0.115903 & 8.499985 & 15.89210 & 0.4892 \\
At most 5 & 0.081321 & 5.852492 & 9.164546 & 0.2024 \\
\hline \hline
\end{tabular}

Max-eigenvalue test indicates 1 cointegrating eqn(s) at the 0.05 level

* denotes rejection of the hypothesis at the 0.05 level

**MacKinnon-Haug-Michelis (1999) p-values 

Cycles and Achieving Macroprudential Objective

This page is intentionally left blank 